\title{
Alienation, Unhomeliness and Desire for Belonging in K.S. Maniam's The Return
}

\author{
Seyedeh Robabeh Zabihzadeh ${ }^{1}$, Ruzy Suliza Hashim ${ }^{1} \&$ Raihanah Mohd Mydin ${ }^{1}$ \\ ${ }^{1}$ School of Language Studies and Linguistics, Universiti Kebangsaan Malaysia, Bangi, Malaysia \\ Correspondence: Seyedeh Robabeh Zabihzadeh, School of Language Studies and Linguistics, Universiti \\ Kebangsaan Malaysia, Bangi, Malaysia. E-mail: r.zabihzadeh@yahoo.com
}

Received: November 28, 2016 Accepted: May 2, 2017 Online Published: May 30, 2017

doi:10.5539/ells.v7n2p120 URL: http://doi.org/10.5539/ells.v7n2p120

\begin{abstract}
Malaysia is a multicultural and multi ethnic society in which national and ethnic identities are very critical and widely disputed issues. Accordingly, several Malaysian writers such as K.S. Maniam have addressed the issues in their literary productions. This paper intends to examine the dilemmas, agonies and desolations of Indian community in Malaysia which have been reflected in K.S. Maniam's autobiographical novel The Return (1981). In the story, Maniam voices out the experiences of Indian minority in the troubled times of Malaysia and their struggle for assimilation and adaptation to the new land as well as their identity crisis. Central characters of the story, Ravi, Periathai and Naina as three different generations of Indian migrant in the landscape of Malaysia attempt to embrace the new land as their home and build their coherent or homogeneous Malaysian identity. This paper also explores Maniam's protagonist's (Ravi) identity conflicts and his endeavor to escape from his unsettled identity as an Indian Malaysian. Ravi seeks his identity in mastering English, the colonial language, yet this is the very point of his alienation as he finds out that all his preconceptions about language was false and illusionary.
\end{abstract}

Keywords: identity crisis, alienation, land, home, belonging

\section{Introduction}

Malaysia is one such country in which a dialectical bond exists between literature and history (De Souza, 2001; Raihanah, 2009). It is therefore crucial to bear in mind that, in the process of examining this bond, the respective functions of literature and history should not be viewed as those of distinctive entities. This is exemplified in K. S. Maniam's literary productions particularly in his novel The Return, in which the initial tracing of the link between the impact of history and history itself can be quite challenging. The narratives of K.S. Maniam are concerned with the legacies of colonialism, imperialism, and particularly with the consequences of the peoples' migrations to the various colonies. In fact, he narrates the life story of the third generation descendants of the Indians who migrated to the Malaysia "during the nineteenth century and are now torn between the pull of their past and their material ambitions in a modern nation officially committed to multiculturalism but alienating to all cultures" (McLaren, 2001, p. 134). The human background from which Maniam like many other migrant Indians came was the vast labor force who migrated to Malaysia to work on the rubber, tea, and oil palm plantations (Wicks, 2007). Maniam himself, as a descendant of Indian family who migrated to Malaysia experienced both colonial and post-colonial period of Malaysia. In fact, as it can be traced in his texts, Maniam is known to be the author of a particular setting during a particular period of time, which is, "from British Malaya to Malaysia" (Wicks, 2007, p. 6). Therefore the central motifs and themes in his works are concerned to colonial and post-colonial issues such as alienation, unhomeliness, displacement, identity construction, nationhood, sense of belonging and personal and political challenges of living in a multicultural society.

In most of his works Maniam provides the readers with a vivid descriptive picture of rural life in Malaysia from the Tamil Indian Malaysian perspective from a rural area and rubber estate on the north part of the Malay Peninsula. Such viewpoint from the frontier, in addition to a strong Hindu spirituality and a craving for the English language, constitute the core of Maniam's life and literary productions (Wicks, 2007). He highlights the tenuousness of belonging and identity construction for immigrant communities, aside from the marginality of Indian Malaysians and emphasizes on the importance of land in identity construction. For clinging and attachment to Hindu mythology and Indian Community, their customs, cultures and rituals, Maniam has been 
reproached "by critics of living under the coconut shell oh his community" (Wan, 2009, p. 15)

This paper explores themes of alienation, unhomeliness and desire for belonging in Maniam's first novel The Return (1981) which is largely autobiographical. The Return is the story of a young impressionable Malaysian Indian boy named Ravi from a third-generation Indian immigrant family in Malaya, who feels lost in the conflict between cultures. In an effort to avoid demands to preserve his grandparent's ancestral culture, as well as the expectations of the Malaysian society for cultural and linguistic assimilation, Ravi flees to an English school. There he learns not only the language, but also the mindset and customs of the former colonial power and this increasingly distances him from his family. After two years of teacher-training in Britain, Ravi comes back to Malaysia in order to confront the dualities of the Malaysian culture, language, landscape and his Indian roots. However, in the course of the story it can be perceived that "these two realities are barely compatible, for the principal characters spend most of the novel in a futile attempt over half a century to put down South Indian roots in Malaysian" (Wicks, 2002, p. 5).

\section{Literature Review}

Dalai (2006) in his article entitled Poetics Of Polyglossia In The Island Diaspora: A Reading Of K. S. Maniam's The Return argues that K.S. Maniam in his autobiographical novel The Return describes the protagonist Ravi's journey of self-knowledge and identity construction as an Indian descendant growing in Malaysia. In the context of post independent Malaysia, Maniam depicts Ravi's life with his family in the hospital compound, his desire for enlightenment through mastering English language, his conflict with the administrator of the hospital compound Mr. Menon, and more importantly the endeavor of an Indian Malaysian for settlement in a foreign land such as Malaysia. Dalai believes that Maniam in The Return tries to seek solutions for living of minority immigrant groups of society such as Indian community in Malaysia who are marginalized in such multicultural and multiethnic third world countries. He argues that Maniam's novel divulges Ravi's perpetual negotiations with several dominant forces including "colonialism, English education, colonial representatives, parental pressure, native resistance, and above all his career and struggle for survival in a multicultural and multilingual Malaysia" (p. 16).

In chapter two of his thesis entitled The Dynamics Of Literary Representation And Interpretation In A Multilingual Environment: A Study Of Selected Malaysian And Singapore Novels In English, Puthucheary (2005) considers alienation as a central theme of K.S. Maniam's autobiographical novel, The Return. He notes that as the title suggests, the return is Ravi's return to his Indian community and Tamil speaking family after two years of alienation in England. The adult Ravi, after two years of teacher-training in England, returns to realize how "his colonial education constructed his sense of self before he can challenge the caste system, the Indian religious belief he wants to modify" (p. 44). Ravi's obsession for mastering English as a means of entering and belonging to the world of fairy tales and authority juxtaposes with his Tamil-speaking environment. Such juxtaposition is evident in mimetic translation of English in dialogues by Tamil-speaking world of Ravi's Indian community. Puthucheary chooses numerous mimetic translation excerpts from Tamil into English in the novel to describe Ravi's ambivalence. He argues that Maniam in The Return "captures the typical Tamil diction by the inflection and syntax of the utterance, when young Ravi's mother calls out to his father, 'Eh, Ravi's father, come and look at this boy!" (p. 46). This excerpt from the novel, as Puthucheary postulates, represents the Indian dialect and culture as it is culturally expected from Indian women not to call their husbands by their names. In order to avoid and escape his own identity and community and their dialectical English diction, Ravi travels to England to master English language but there he realizes that the he cannot find his identity in English language. According to Puthucheary, therefore in his life's quest after all his struggles through the journey of self-discovery, Ravi reconciles with his Tamil speaking family and embraces his community.

In Parameters of Malaysian Identity In The Novels of Lloyd Fernando And K.S. Maniam Peter Wicks (2002) states that Maniam's first novel The Return is vastly "replete with Indian symbols and characters that readers could be forgiven for inferring that British Malaya of the 1950s was a mostly Indian preserve" (p. 5). He considers Ravi's Grandmother, Periathai, as the authentic embodiment and epitome of Indian past and culture. Wicks points outs that the story of Periathai which is based on Maniam's own grandmother "serves to confirm Edward Said's view of narrative as the method colonized people use to assert their own identity and the existence of their own history" (p. 5). Periathai fails to own her house or a piece of land in Malysia which conceptualizes identity and belonging, yet her testament to Ravi was never to let anything break his identity, sense of self, and spirit. Wicks further highlights the communalism in the story particularly among Ravi's family and describes it as the situation in which one's ultimate devotion and regard is given to his ethnic community. According to him, communalism in the story on one hand helped creating temporary personal identity and cultural vitality in the adopted land, until memory disappears gradually, and replaces with reminiscence and a 
despondent sense of cultural loss. However, "on the other hand, an aspect of Tamil communalism such as caste restrained the upward social mobility, occupational choice, and material success that the new circumstances of Malaya/Malaysia warranted and encouraged" (p. 6). Wicks further posits that Ravi who had faced the sense cultural loss and escaped from his identity and community finally discovered that he could only assert his identity through reconciliation and adaptation to his environment.

In his 2007 published paper entitled K. S. Maniam: Malaysian Writer Wicks describes K.S. Maniam as a prolific writer with critically-acclaimed literary achievements and numerous short stories, three plays and novels who is denied public popularity and acclaim in his own country because of his medium of writing which is English rather than BahasaMelayu, the national and official language in Malaysia. He elucidates that Maniam's literary productions "are imbued with the vibrancy of the Malaysian landscape, both human and physical" (p. 1) and particularly by the images of life and cultures of his own Indian Malaysian community. Wicks also refers to school as a key institution in Maniam's literary works which represents "the possibilities of systematic, structured learning, of upward social mobility, of self-actualization, and most importantly, of escape even during the late British colonial period" (p. 5) in Malaysia. Ravi, the central character of Maniam's autobiographical novel The Return, first attended the Tamil-medium primary school which was associated with Indian culture through entrancing stories of elephants, deer, snakes and mongooses in the Tamil written textbooks and pamphlets. The next year, Ravi was sent to an English-medium school which represents colonial power and authority. There Ravi experienced a different system of education with Miss Nancy, the teacher who was obsessed with "fantasies like Snow White and the Seven Dwarfs, and also with discipline and bodily hygiene". In these two different worlds of Tamil and English-medium schools Ravi encountered a duality between his indigenous and non-indigenous culture. For Ravi, after attending English school, "the worlds of school and home began to lurch dramatically and disturbingly apart, and he came to view his Indian domesticity with disdain, employing negative terms like "darkness," "futility," and "primitive,"” (p. 6) to describe his own indigenous community, customs and culture.

Raihanah (2009) in her article entitled Malaysia and The Author: Face-To-Face With The Challenges Of Multiculturalism states that K.S. Maniam in his fiction, not only narrates the story of his own community, the Malaysian Indian, but he perhaps more importantly speaks to them. In Maniam's narration, Indians are in a constant attempt to find a place for their culture and religion in the adopted land of Malaysia. Raihanah is of the view that Maniam's fiction focuses on the challengesen countered by both the Indian migrant community and every individual member of the said community as they endeavor to cultivate a sense of belonging in a new and foreign land yet oscillate between their ethno-cultural attachments and the adopted culture.

However, this study highlights the fragility of migration and immigrants' frustration as a part and parcel of it. To be more specific, it explores Maniam's characters' devastation in building a homogenous identity in the adopted land and creating a sense of attachment and belonging to the host country. It examines Maniam's depiction of Indians' unhomeliness and in-betweenness in Malaysia and how they failed to maintain their ancestral Indian identity and accordingly experienced alienation from their very own community. In addition, Maniam's characters felt ambivalent with their in-between identity owing to their frustration in building a new identity and therefore felt alienated from the host community.

\section{Conceptual Theory}

According to Bhugra \& Becker (2005), there are three phases that make up the gist of migration, irrespective of the causes that have led to its fruition. The first phase, otherwise known as "pre-migration", constitutes an individual's or a group's resolution to migrate and subsequently undertake whatever that is necessary to aid said individual or group when the time has come to migrate. This phase of pre-migration is followed by phase two, better known as "physical relocation". This is the phase where the aforementioned individual or group embark on the journey to a new home or, to simply put it, the very act of migrating itself. In the third and final phase, otherwise called "post-migration", said individual or group, otherwise termed as an immigrant or immigrants, blends into and learns the ways of the adopted land. That being said, Rumbaut (2015) posits the view that the process of blending in, or assimilation, as a many-faceted progression that not only minimizes borders but also erases racial and ethnic differences as well as the socio-cultural uniqueness and divisions linked to said differences, is bound to take place in the final phase of post-migration. He also postulates that the aforementioned blending in or assimilation tends to differ by number; in this context, at the individual level, assimilation symbolizes the myriad of changes that compel immigrants of a particular race or nationality to develop a sense of affinity with another race or nation, whereas for a group of immigrants at the collective level, assimilation refers to the process in which said group finds itself being gradually integrated into the general society of a new home. 
Bhugra \& Jones (2001), on the other hand, are of the view that a newly-arrived immigrant is susceptible to detachment and segregation not only from the community of a new land, but also from said immigrant's own kind, thanks to a host of impediments ranging from cultural and linguistic differences to hurdles in job-hunting and the search for accommodation. This, according to Bhugra \& Jones (2001), is because assimilation is, more often than not, responsible for the disintegration of one's affiliation or sense of belonging towards both birthplace and new homeland. As such, one might lose the sense of belonging during assimilation process to both ancestral homeland and adopted land. Having said that, Bhugra \& Becker (2005) assert that migration is thus accountable for losses that go beyond the loss of one's birthplace, namely "the loss of one's social structure and culture" (p. 19) as well as the "loss of the familiar, including language (especially colloquial and dialect), attitudes, values, social structures and support networks" (p. 19). Owing to the onslaught of these radical alterations, the gradual extinguishing of cultural identity becomes a risk for the immigrant. Subsequently, the immigrant also ends up at a crossroads in which a constant dilemma of fully embracing the ways of an adopted homeland at the expense of discarding those unique to the birthplace or land of origin persists.

Should an immigrant suffer from the inability to blend in and adjust to the ways of the adopted or new homeland, there is a tendency for the aforementioned immigrant to feel segregated and culturally dislodged. According to Papastergiadis (2013), failure in assimilation and acculturation creates a sense of cultural displacement and alienation in the immigrants, which is generally accompanied by a broader reconsidering of one's identity and social stand. In other words, the experience of alienation in the adopted land, in turn, culminates into the questioning and re-evaluation of such wider concepts as personal identity and position in society. When this occurs, an immigrant may learn that the adopted land is somewhat hostile to his/her identity and, more often than not, said immigrant ends up feeling "unhomely" as a consequence. Homi Bhabha (1994), on the other hand, contends that the sense of being "unhomed" is not akin to homelessness. His view is reiterated by Tyson (2014), who posits that immigrants are transformed into "psychological refugees" upon being "unhomed", because "unhomeliness" makes strangers out of us even within our own homes as there is no longer a feeling of being at home with the self or, to phrase it better, we are already engulfed in a dilemma involving our respective cultural identities.

Several scholars including Chun (2014) and Bressler (2007) postulate that the concept of unhomeliness encompasses the notion of being neither here nor there within the crossroads of two cultures, which can also be psychological by nature, because it stems not only from some psychological turmoil but also from the distress caused by cultural displacement. To this, Bhabha (1994) describes said concept as the "condition of extra-territorial and cross-cultural initiations" (p. 13). In this context, Bhabha (1994) himself has posited that unhomeliness is indeed more than physical and goes beyond the shifting of persons from one place to another; it also involves the shifting of persons from one culture to another. As such, the state of unhomeliness can also be summarized as the inability of a house on alien soil to function as a suitable substitute of an individual's original home, due in part to the ties that bind said individual to the original homeland. Having said that, this view goes in tandem with the findings of Ashcroft et al. (2004), who postulate that the geographical scattering of peoples is not the sole component of migration; rather, migration is also about addressing the nagging issues of identity, home and memory put forward by said geographical scattering.

In accordance to what has been said, it can be argued that in Maniam's The Return as the story involves in the Indian's migration to Malaysia, the juxtaposition of losing Indian spiritual identity and adopting the identity of the new land in the assimilation process is an inevitable experience that prevails in Ravi's family's life. The main characters of the story, Ravi, Naina and Periathai, are in an in-between space and are torn between their ancestral culture and adopted culture which brings them a sense of dislocation and disposition. As such they fail in building a solid identity since they neither belong to the homeland nor to the adopted land thanks to their failure in getting the ownership right of the land they have lived on. Thus, despite their effort to get along with the adopted land, Maniam's characters in the story undergo a deep frustration as they suffer from unhomeliness both psychical and psychological. The following section will explore the themes of alienation, unhomeliness and desire for belonging in the life of Periathai, Naina and Ravi that in a broader sense reflect the marginalization of Indian community in the land of Malaysia.

\section{Textual Analysis}

K. S. Maniam's first novel, The Return (1981), is a nostalgic narrative told in flashbacks from the protagonist Ravi's point of view. At the exposition of the narrative, the reader is introduced to Periathai, also known as "Big Mother". Here, the narrator recounts Periathai's hardships in her new home, Malaysia, as a migrant woman from India with three young sons. To earn a living, she initiates herself in the business of tinkering and healing before turning to till the land she considers her own. This part of the narrative offers a pitiable and compelling insight 
into a matriarch's struggle to raise her family on alien soil, only to find that the home she had toiled to erect is under threat from destruction, while her now-adult sons venture in and out of their adopted land.

Ravi then enters the narrative himself, exposing to readers about his childhood days in the "long house" that he grew up in, which is actually a hospital compound. Here, a vivid picture of society during a particular period in Malaysian history can be obtained through an understanding of the challenges experienced by Ravi and his community. Being a first-generation Malaysian Indian, Ravi's nationality and identity are a collective source of many questions that he will ask himself at various points in the narrative. This, in fact, evolves into a dilemma that haunts him from his childhood until he becomes an English-educated adult, as exemplified below.

How does one describe the land one lives in but never saw? (Maniam, 1981, p. 14)

In the narrative, Maniam does not elaborate on the status of the Malaysian Indians as a smaller ethnic group, unlike the larger Malay and Chinese communities that are engaged in a rivalry for control over the country's politics and economy at that time, mainly because of the fact that the other residents of the hospital compound Ravi grew up in, presided over by Menon, a man known as "Ayah" or "chief", all happen to be Indians like him. Nevertheless, Ravi is aware of his and his family's lowly position within the community. In the narrative, it is revealed that Ravi's father, Naina, is a very hardworking man who is paid to do the hospital laundry as well as for those who can afford it, and that the entire family, including Ravi, whose part involves the delivery of freshly-laundered clothes, assists Naina in his job. Despite their diligence, however, they seem fated to remain in the same economically-deprived situation. Perhaps this is what compels Ravi's stepmother, Karupi, to egg his father on about a dream that she had, in which she believes that she was asked to enroll Ravi in the English school. Ravi's identity crisis deepens as a result of his initiation into the English education system, as his ongoing individual process of identifying of self and origin, spurred by his earlier Tamil education as exemplified below, is subjected to sudden and quick changes.

Murugesu, drafted into the school begun only that year, had proved to be more than a teacher. I saw him poised and pulling us to urgent discovery. He added the other familiar dimension to my landscape. The textbooks, specially ordered from India, contained fields, jungles and characters I felt for and understood. (Maniam, 1981, p. 20)

In a way, the English education suddenly foisted upon Ravi can be interpreted in its initial stage as some sort of cultural assault. This is apparent when everything considered commonplace for Indian boys like Ravi, such as the practice of going to school without brushing one's teeth, are viewed with distaste and subsequently banned by Miss Nancy, the English teacher, who also considers coconut oil, traditionally applied to the hair by Indians, as "rotten butter". Indeed, Ravi's first English teacher, Miss Nancy, can be seen as the instiller of colonial culture, because it is she who moulds the mindsets and lifestyles of Ravi and his classmates as part of the process of initiation into the insights of social mobility. This is also evident in the narrative when Miss Nancy subtly presents a condescending view of traditional Indian socio-cultural practices through her cunning reenactment of fairy tales to counter whatever Murugesu, the teacher from the Tamil school, has taught the boys. It is through Miss Nancy that the boys are initiated into new ways of thinking, which are anathema to the traditional values, beliefs and practices that they were raised with. A notable example would be the narration of her own version of the children's tale Hansel and Gretel, in which she provides the boys with a graphic description of how the evil witch, who dies in the original story, gets to devour Hansel piece by piece. While this brings to Ravi's mind the slaughtering of goats, a significant ritual of the Hindu festival of Deepavali, it inculcates within him a view of his own culture as horrible and stupid. Here, Ravi experiences a form of isolation and marginalization thanks to his Anglicization under Miss Nancy, in which he finds himself despising and viewing with disdain the very community that he belongs to. This is evident when he starts to perceive the attitudes and behaviors of his fellow Indians in the hospital compound, such as gossiping and talk of trivial matters among the women, not to mention the constant fights and slandering, as repulsive and even irrelevant. Here, it can be postulated that Ravi's personal goal for excelling in his English education is not inspired by the need to grant his family upward social mobility, away from their menial job as launderers. Rather, it is simply because he just wants to isolate himself from his own family. This has led to a misunderstanding between him and his family, which eventually results in him staying out of the clamor, quarrels and disputes at home, resorting instead to his English schoolbooks and comic magazines for company.

Gradually, Ravi sees more of his friends in school and less of those from his community. At this point, his childhood friends from his community notice the change in him and subsequently view him in a different light, mocking him with degrading sobriquets such as "white monkey". Undeterred, Ravi, having inherited Periathai's and Naina's industrious streak, continues to pursue his studies, impervious to the goings-on in his family and 
community. However, despite his ambitions, Ravi is constantly haunted by painful reminders of his lowly status in his own community, as evidenced in the "yellow line" that separates the denizens of the hospital compound based on class. In the narrative, it is revealed that a curious Ravi once crossed that line and was given a beating by Ayah as a result. Thanks to this experience, Ravi's disdain towards the traditions and customs of his community has clearly eliminated any longing for clinging to his culture, as exemplified below.

I don't know what promises I made myself but a grain of iron must have entered my soul for, from the following day, I turned away from the God who ruled my people. (Maniam, 1981, p. 79)

Undeniably, class-based discrimination in Malaysian Indian communities, such as Ravi's, is evident in the narrative. In the story, Ravi is depicted to be constantly struggling to achieve his dreams while others simply fritter their luxuries away. Menon, the Ayah, feels his authority under threat when Ravi excels in the English school and has acquired substantial knowledge of the English language, which was the language of authority in those days, compelling the former to have the schooling of the latter stopped by force. Ravi, however, receives support from his father, Naina, who makes a compromise with Menon that Ravi must be allowed to continue studying on condition that he can financially support himself. This only fuels Ravi's initiative even more, to the point that he is awarded with a scholarship to enter secondary school. In the narrative, we learn that Naina has sacrificed much so that Ravi can complete his primary school education. Nevertheless, he expands their laundering business in the city following threats against his family as well as the unending gossip about the compromise he made with Menon. At this point, Ravi learns to be even more independent as he acquires a room of his own while working and pursuing his education simultaneously. As his family business attains success, the nation is gearing up for independence as well. Through Ravi's perspective, a city has literally grown in front of him.

In the narrative, it is revealed that with each historical milestone in Malaysia, notably Independence in 1957 and the end of the Emergency in 1960, Ravi's family has also been consistent in adapting to the various changes visited upon them, prospering in the process and moving into a place of their own away from the hospital compound despite the arrival of new traders and the rift between Naina and Menon. By now, Menon's resentment towards Ravi's family, initially caused by Ravi's schooling in spite of his protests, has intensified due to the success of Naina's laundry business, but Naina remains undeterred, for his main objective as the family's sole breadwinner is to feed his children, aside from the fact that he no longer wants to please others at his expense. However, a dark cloud soon passes over Ravi's family when Periathai passes away. By now, they have already relocated to the city and are doing reasonably well. Given that he is the only son around, Naina shoulders full responsibility for the financing and materialization of Periathai's last rites, but something is not entirely right at this point. In the novel, it is revealed that Naina has made a public spectacle out of Periathai's funeral, going to great lengths to ensure that everyone in town knows of her demise and thus failing to maintain the austerity of the occasion. While this may suggest the breakdown of class boundaries through Naina's imposition of his newfound economic power, it nevertheless brings huge financial loss to Ravi's family, although Naina does not lose hope in fulfilling Periathai's dream of having a home and struggles to earn what he lost by planning another expansion of the family business.

This time, however, Ravi's stepmother Karupi takes the lead due to Naina's increasing neurotic tendencies, presiding over the home and business reasonably well. Now, Ravi's main priority is still his studies, as he is about to obtain his teaching bursary and travel to England, the land of his dreams. Although Ravi describes his trip to England only in passing, he does not contain his triumph in getting the opportunity to educate the children of the Englishmen. His revelry, however, is quickly dispelled upon his arrival home, where the sights and scents of his childhood, which he had been successfully avoiding, return to him. As he returns to find the family shop empty with only Karupi and his siblings in it, he discovers the extent of the losses Naina has put them through to get their own house built, a dream that sadly went up in flames when the government not only posed restrictions against it, but also threatened to have them evicted. However, Naina remains obstinate and continues to demand Ravi for his salary in spite of protests from the latter. The pursuit of fulfilling Periathai's dream of being housed in the new adopted land finally takes its toll on Naina, who is now reduced to mumbling and self-confinement in the prayer room. Naina constantly remembers Periathai's endless effort to settle her own family in the adopted land of Malaysia, and her desire to possess the land that she has built the house on and had occupied it "long enough to be its rightful heir" (Maniam, 1981, p. 9). Nevertheless, since she only has a "vague belief and a dubious loyalty" (Maniam, 1981, p. 8) instead of a written deed to prove her ownership of the land, she failed to get the ownership rights and to be housed in the adopted land.

In the story it is revealed that Periathai died unhomely upon her failure to earn a home/land and to shape her identity in Malaysia. After Periathai's death, Naina fights to own the house and its land yet he fails to affiliate to 
the land. Like Periathai, till his dying day, the zeal to firmly root himself in Malaysia, despite the fact that it is not his birthplace, has been omnipresent in Naina. Indeed, this story can be read as an allegory of the Third World, as it recounts the plight of a minority community in Malaysia's formative years. It may thus seem baffling that Malaysian Indians are not featured as prominently as they should have been in mainstream historical narratives. However, their contributions to Malaysia's growth in general, signified by their unrequited willingness to adapt to change and abide by the laws of the land has made them all the more alluring in the examination of Malaysia's rich postcolonial history.

\section{Conclusion}

The questions of cultural identity in an immigrant society, racism and its impact on multi-ethnic landscape of Malaysia and sense of belonging prevail in most of K. S. Maniam's literary productions particularly his novels In a Far Country and The Return. In fact, The Return criticizes "Malaysia's communal isolation and development, its lack of a genuinely inclusive multicultural policy, and its elevation of one race and religion above everything" (Lim, 2004, p. 56). Maniam's main focus in The Return is largely on alienated, estranged individuals struggling to build their homogenous identity and "make something of themselves in an unhomely world, all longing to belong but constantly reminded of their marginal place in Malay-Islamic Scheme of things" (Lim, 2004, p. 56). In the novel, Ravi and the entire Indian community are assimilating into a country that is struggling for independence and decolonization. In such country, the immigrants are obliged to adapt and conform by abandoning their ancestral traditions and values when they acquaint themselves with those of the host society. The immigrants would be judged by the degree to which they embrace, accept and conform to the norms of the host country even at the risk of their own cultures and traditions (Vigdor, 2015). As implied by Pillai (2004), in the context of The Return, individuals like Periathai, Naina, and Ravi "transfigured ancestral lore..., from the liminality of the migrant experience into the transcultured space of citizenship of a diasporic existence, seeking to belong to a new homeland" (p. 233). However, in Maniam's narration, the need to belong to the borrowed land that they could not claim gradually reduced the entire Indian community and in a narrower scope Ravi and his family to a marginalized population. In the case of Ravi who fights for a better life in the new land, where he has become the victim of racial discrimination and marginalization, by assimilating into the dominant culture, he "eventually suffers a sharpened sense of marginalization at the hands of his own community members" (Raihanah et al., 2011) over and above the host society.

Our analysis of Maniam's articulation in The Return has revealed that Periathai, Naina, and Ravi failed to embrace the land and find their place in the adopted country by possessing a piece of land for themselves as a home. Such failure in land ownership brought the sense of unhomeliness to them and subsequently they lost their sense of belonging. Likewise, it can be argued that in the novel Periathai, Naina, and Ravi as three generations of Indian Malaysians not only failed to build their own individual identity and sense of self in the adopted land but they also failed to assert the homogenous communal identity. We would like to postulate this is not a result of the main protagonist Ravi's family's account as individuals rather, it is due to the fact that during the timeframe in which the narrative is set, Malaysian Indians have been somewhat "overlooked" in the grander scheme of things that form the crux of Malaysia's nation-building process. In this context, it can be argued that a number of Malaysian Indians have striven to move history forward through their contributions to Malaysia's socio-economical fabric, but many have been denied acknowledgment as prominent figures in mainstream historical narratives.

\section{Acknowledgement}

A part of this paper has been presented in SoLLs.INTEC.15 conference. This research was funded by GUP-2014-024 Grant.

\section{References}

Ashcroft, B., Griffiths, G., \& Tiffin, H. (2004). The empire writes back: Theory and practice in post-colonial literatures. London, New York: Routledge.

Bhabha, K. H. (1994). The Location of Culture. New York: Routledge.

Bhugra, D., \& Becker, M. A. (2005). Migration, cultural bereavement and cultural identity. World Psychiatry, $4(1), 18-24$.

Bhugra, D., \& Jones, P. (2001). Migration and mental illness. Advances in Psychiatric Treatment, 7(3), 216-222. https://doi.org/10.1192/apt.7.3.216

Bressler, E. C. (2007). Literary Criticism: An Introduction to Theory and Practice (4th ed.). New Jersey: Pearson Prentice Hall. 
Chun, Y. (2014). A Realistic Portrayal of Reservation Life: A Postcolonial Reading of the Absolutely True Diary of a Part-Time Indian. Sino-US English Teaching, 11(1), 83-88.

Dalai, P. (2006). Poetics of Polyglossia in The Island Diaspora: A Reading of K. S. Maniam's The Return.

De Souza, D. (2001). The roots of Malay [an] literature in English. Malaysian Literature in English: A Critical Reader, 2-13.

Lim, D. C. (2004). The Infinite Longing for Home: Desire and the Nation in a selected Writings of Ben Okri and K.S. Maniam. Editions Rodopi BV.

Maniam, K. S. (1981). The Return. London: Skoob Books Pub Ltd.

McLaren, J. (2001). States of Imagination: Nationalism, citizenship and multiculturalism in writings from Australia and Southern Asia (Doctoral dissertation, Australian Scholarly Publishing). Retrieved from http://vuir.vu.edu.au/id/eprint/369

Papastergiadis, N. (2013). The turbulence of migration: globalization, deterritorialization and hybridity. New York: John Wiley \& Sons.

Pillai, S. (2004). Dislodging imperial crates of subalternity: A study of the representations of the Indian coolie experience of colonial Malaya (Doctoral dissertation).

Puthucheary, R. J. (2005). The Dynamics of Literary Representation and Interpretation in a Multilingual Environment: A Study of Selected Malaysian and Singapore Novels in English. National University of Singapore.

Raihanah, M. M. (2009). Malaysia and the author: Face-to-face with the challenges of multiculturalism. IJAPS, $5(2), 43-63$.

Raihanah, M. M., Ruzy, S. H., \& Noraini, M. Y. (2011). Themes Of Recognition And Reification In Ks Maniam's Novels. Kajian Malaysia, 29(2), 31-45.

Rumbaut, R. G. (2015). Assimilation of immigrants. International Encyclopedia of the Social \& Behavioral Sciences, 2, 81-87. https://doi.org/10.1016/B978-0-08-097086-8.31109-6

Tyson, L. (2014). Critical theory today: A user-friendly guide. London, New York: Routledge.

Vigdor, J. (2015). The Civic and Cultural Assimilation of Immigrants to the United States. The Economics of Immigration: Market-Based Approaches, Social Science, and Public Policy.

Wan, R. W. Y. (2009). Silence, Suffering and The Female Voice In pLays By K.S.Maniam and Sarah Daniels. Penerbit University Putra Malaysia.

Wicks, P. (2002). Parameters of Malaysian identity in the novels of Lloyd Fernando and K. S. Maniam. Asian Profile, 30(1), 27-36.

Wicks, P. (2007). K S Maniam: Malaysian Writer. The Literary Encyclopedia. University of Southern Queensland.

\section{Copyrights}

Copyright for this article is retained by the author, with first publication rights granted to the journal.

This is an open-access article distributed under the terms and conditions of the Creative Commons Attribution license (http://creativecommons.org/licenses/by/4.0/). 